\title{
RELATIONSHIP BETWEEN FRUIT MATURATION STAGE AND PHYSIOLOGICAL QUALITY OF PHYSIC NUT (Jatropha curcas L.) SEEDS
}

\author{
Relação entre estádio de maturação dos frutos e qualidade fisiológica \\ de sementes de pinhão manso (Jatropha curcas L.)
}

\author{
Laércio Junio da Silva ${ }^{1}$, Denise Cunha Fernandes dos Santos Dias², \\ Carla do Carmo Milagres ${ }^{1}$, Luiz Antônio dos Santos Dias ${ }^{1}$
}

\begin{abstract}
The physic nut (Jatropha curcas L.) has great potential for use in biodiesel production due to the high oil content of its seeds. Production of high quality seeds depends upon the appropriate time of harvest. A field experiment was carried out to monitor the maturation process of physic nut seeds and to establish the ideal harvest time of the seeds based on external fruit color. Fruits were collected at different maturation stages based on the external color: green, yellow-green, yellow, yellow-brown and brown. Seeds were extracted manually and, after natural drying, were submitted to the following tests and determinations: moisture content and dry matter, germination, first count seedling emergence, seedling growth, accelerated aging, electrical conductivity, the weight of thousand seeds and oil content. A randomized design was used with four replications. Data were subjected to analysis of variance and, for each test, treatment means were compared by Tukey test at 5\% probability. Physic nut seeds with high physiological quality are obtained from yellow and yellow-brown fruits. Seeds from green fruits have lower physiological quality, dry matter and oil content than the other maturation stages. The seeds obtained from brown fruits have a high germination potential, but have low vigor in relation to yellow and yellow-brown stages.
\end{abstract}

Index terms: Germination, vigor, harvest, maturity.

\section{RESUMO}

O pinhão manso (Jatropha curcas L.) tem grande potencial para ser utilizado na produção de biodiesel, pelo elevado teor de óleo de suas sementes. A colheita das sementes em momento adequado é fundamental para se obter sementes de elevada qualidade. Foi conduzido um experimento de campo para monitorar o processo de maturação das sementes de pinhão e estabelecer o ponto ideal para a colheita das sementes com base na coloração dos frutos. Para isso, foram colhidos frutos em diferentes estádios de maturação com base na coloração externa: verde, verde-amarelo, amarelo, amarelo-marrom e marrom. As sementes foram extraídas manualmente e, após secagem natural, foram submetidas aos seguintes testes e determinações: grau de umidade e massa seca, germinação, primeira contagem de germinação, emergência de plântulas, crescimento de plântulas, envelhecimento acelerado, condutividade elétrica, peso de mil sementes e teor de óleo. Utilizou-se o delineamento inteiramente casualizado, com quatro repetições. Os dados foram submetidos à análise de variância e, para cada teste, as médias dos tratamentos foram comparadas pelo teste de Tukey (p < 0.05). Sementes de pinhão manso de alta qualidade fisiológica são obtidas de frutos amarelos e amarelo-marrons. Sementes obtidas de frutos verdes têm menor conteúdo de massa seca, de óleo e qualidade fisiológica inferior às dos demais estádios de maturação. As sementes obtidas de frutos marrons possuem elevado potencial de germinação, no entanto apresentam menor vigor em relação às dos estádios amarelo e amarelo-marrom.

Termos para indexação: Germinação, vigor, colheita, maturidade.

\section{(Received in november 4, 2011 and approved in january 12, 2012)}

\section{INTRODUCTION}

Jatropha curcas L. (Euphorbiaceae) commonly known as the "physic nut", is a tropical shrub with seeds rich in oil that meet the standard for use as biodiesel (TIWARI et al., 2007). Although the plant can be propagated through cuttings, seed propagation is more common. Information regarding seed production and technology, especially regarding seed maturation, are scarce.
Fruit harvesting at an adequate maturation stage is one of the factors that determines seed quality. Therefore, determination of the stage of maximum seed quality during fruit development is essential, especially in plant species such as physic nut that have indeterminate fruiting periods (SILIP et al., 2010). Obtaining high quality seeds in such species is difficult because fruits at different developmental stage are found not only on the same plant but also in the same fruit

'Universidade Federal de Viçosa/UFV - Viçosa - MG - Brasil

${ }^{2}$ Universidade Federal de Viçosa/UFV - Departamento de Fitotecnia - Avenida PH Rolfs - s/n - 36570-000 - Viçosa - MG - Brasil - dcdias@ufv.br 
bunch. Fixing the number of days after anthesis, flowering or fructification can vary with cultivar and the environmental conditions (DIAS et al., 2006a). Therefore, easily identifiable fruit maturation characteristics that relate to seeds quality are essential to determine the optimum fruit harvest stage (DIAS et al., 2006b).

In many plant species the seed moisture content, morphological aspects of the plant and/or of the fruit are defined to ascertain the maximum seed quality stage. In physic nut, Kaushik (2003) reported that the vigour of seeds obtained from green fruits is lower than those obtained from yellow or brownish black fruits, and the best physiological quality seeds were obtained from yellow fruits. On the other hand, Albuquerque et al. (2008) obtained higher quality seeds from fruits harvested dry, suggesting that physiological maturity occurred at this stage.

The occurrence of maximum seed quality during development and its association with seed and fruit features are important factors to define the ideal harvest time. The objective of this study was to monitor the maturation process of physic nut seeds and correlate this with the fruit maturation stage determined by the external fruit color.

\section{MATERIAL AND METHODS}

Physic nut (Jatropha curcas L.) plants have been grown in Viçosa, MG, Brazil $\left(42^{\circ} 52^{\prime} 56.77^{\prime \prime W}\right.$, $20^{\circ} 48^{\prime} 37.87 " \mathrm{~S}$ ), since 2006. Fifty plants were selected randomly and approximately 5000 female flowers were tagged at anthesis from November to December 2010. The capsules (fruits) containing three seeds each were harvested during the following maturation stages, characterized by epicarp color: brown, yellowish-brown, yellow, greenish-yellow and green (Figure 1). Initially, the seeds were extracted from fruits and the seed moisture (\% on wet basis) and dry matter content $(\mathrm{mg} / \mathrm{seed})$ were determined, in duplicate samples, by drying at $105 \pm 3^{\circ} \mathrm{C}$ for 24 hours (BRASIL, 2009).

Then, the seeds were dried at room temperature to approximately $8 \%$ moisture content and the following parameters were determined for each maturation stage:

1000-seed weight: eight replications of 100 seeds were weighed $(0.0001 \mathrm{~g})$ and 1000 -seed weight was determined according to procedures described by Rules for Seed Testing (BRASIL, 2009).

Standard germination: eight replications of 25 seeds each were planted in rolled paper towels $\left(\mathrm{JProlab}^{\circledR}\right)$, moistened with water at a proportion of 2.7 times the dry substratum weight, and germinated at $25 \pm 2^{\circ} \mathrm{C}$. Counts were performed at 7, 12 and 17 days after seeding and expressed as mean percentage of normal seedlings. For statistical analysis, the replications were grouped in pairs to form four replications of 50 seeds.

Accelerated aging: the seeds were placed on a wire mesh screen suspended over $40 \mathrm{~mL}$ of water inside a plastic germination box (AOSA, 1983). The boxes were held in an incubator at $41^{\circ} \mathrm{C} \pm 0.5^{\circ} \mathrm{C}$ for 72 hours. After this period, eight replications of 50 seeds each were tested for germination as previously described. The results were expressed as the mean percentage of normal seedlings obtained at 7 days after seeding.

Electrical conductivity: four replicates of 50 seeds each were weighed to $0.01 \mathrm{~g}$, placed into plastic cups with $75 \mathrm{~mL}$ of distilled water, and held at $25^{\circ} \mathrm{C}$ (AOSA, 1983). After 24 hours, the electrical conductivity of the soaked seed solution was determined using a conductivity meter. The mean values were expressed in $\mu \mathrm{S} \mathrm{cm}^{-1} \mathrm{~g}^{-1}$.

Percentage of seedling emergence and speed emergence index: in a greenhouse, plastic trays $(230 \mathrm{x}$ $160 \times 60 \mathrm{~mm})$ were filled with soil + sand $(2: 1)$ moistened at $70 \%$ of retention capacity. Four replications of 25 seeds each were sown $2 \mathrm{~cm}$ deep. Emerged seedlings were counted daily for 17 days. Seedlings were considered emerged when their cotyledons were above the substrate surface. The percentage of seedling emergence and the speed emergence index (SEI) (MAGUIRE, 1962) were calculated.

Seedling length and dry weight: the length $(\mathrm{mm} /$ seedling) of the seedlings obtained in the seedling emergence test was measured 17 days after sowing. Then, seedlings were dried in an oven at $70 \pm 2^{\circ} \mathrm{C}$ for 48 hours and dry weight was determined by weighing $(\mathrm{mg} /$ seedling).

Oil content: the oil content of three replications of seven seeds was determined by the Nuclear Magnetic Resonance method (Oxford Instruments) with the whole seeds. The device was previously calibrated with transesterified Jatropha oil.

Statistical design and analysis: the study was performed in a completely randomized design with four replications. The data obtained for each parameter were subjected to ANOVA using General Linear Model procedure for SAS (SAS INSTITUTE, 2002). The treatments means for each test were compared by Tukey's test $(\mathrm{p}<0.05)$. 


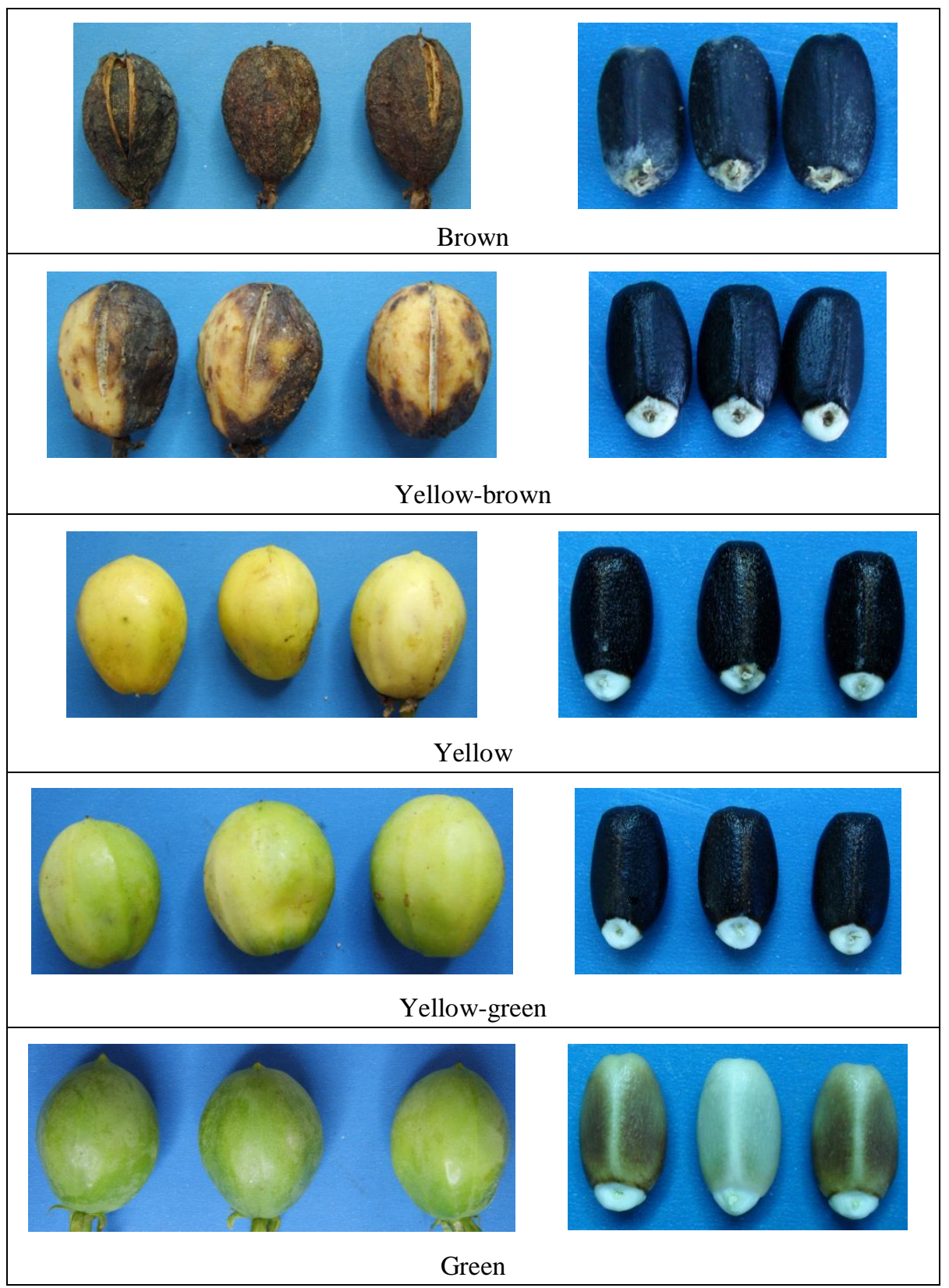

Figure 1 - Visual aspect of physic nut fruits and seeds at different stages of maturation.

\section{RESULTS AND DISCUSSION}

The seeds from green fruits had the highest moisture content $(76.0 \%)$, which started to decrease during the progress of fruit maturation, reaching values between $48.3 \%$ and $52.0 \%$ for seeds from yellowish-brown, yellow, greenishyellow fruits, which did not differ. When the fruits turned brown seed moisture content declined to $17.7 \%$ reaching values between 7.6 to $8.3 \%$ after natural drying at room conditions (Table 1), independent of the harvest stage.

The seed dry weight increased with the maturation process (Table 1), and the highest value was found in seeds from yellowish brown or brown fruits. Lower dry weight values were verified for seeds from green fruits in relation to brown and yellowish-brown fruits. However, the precise

Ciênc. agrotec., Lavras, v. 36, n. 1, p. 39-44, jan./fev., 2012 
stage of dry matter stabilization could not be detected, which would have indicated the end point of translocation of plant assimilate to seeds. Kaushik (2003) reported maximum dry weight in physic nut seeds extracted from yellow fruits. According to Egli and TeKrony (1997), seed dry weight for all species increased at a relatively constant rate over much of the seed filling period. Seed water content is very high shortly after fertilization and declines steadily during development until the seed reaches physiological maturation (ZANAKIS et al., 1994). After this point, the decrease in seed water content continues frequently at a faster rate, until the seed reaches a moisture level suitable for harvest, as found in our work (Table 1). Our results show a rapid decline in the seed moisture content when fruits yellowish-brown changed to brown color outside, probably indicating that physiological maturity of the seeds has been attained (Table 1).

Table 1 - Moisture content after extraction from the fruits (MCF) and after natural drying (MC), dry weight (DW) and 1000-seed weight (PM) of physic nut seeds extracted from fruits harvested at different stages of maturation.

\begin{tabular}{ccccc}
\hline Stages & MCF & MC & DW & PM \\
\hline & $\%$ & $\%$ & mg seed $^{-1}$ & $\mathrm{~g}$ \\
Brown & $17.7 \mathrm{c} *$ & 7.57 & $647.6 \mathrm{a}$ & $678.18 \mathrm{a}$ \\
Yellowish-brown & $48.4 \mathrm{~b}$ & 7.58 & $628.8 \mathrm{a}$ & $635.92 \mathrm{~b}$ \\
Yellow & $48.3 \mathrm{~b}$ & 7.83 & $564.3 \mathrm{ab}$ & $630.19 \mathrm{~b}$ \\
Greenish-yellow & $52.0 \mathrm{~b}$ & 7.92 & $553.4 \mathrm{ab}$ & $568.26 \mathrm{c}$ \\
Green & $76.0 \mathrm{a}$ & 8.36 & $451.0 \mathrm{~b}$ & $494.17 \mathrm{~d}$ \\
\hline C.V. (\%) & 5.98 & & 6.19 & 3.31 \\
\hline
\end{tabular}

* Means followed by the same letter among fruit stage of maturation are not different (Tukey, $\mathrm{p}<0.05$ ).

The 1000-seed weight increased gradually with the progress of fruit maturity (Table 1). The seeds extracted from brown fruits were heaviest, and the seeds obtained from green fruits were lightest. Although seed dry weight did not differ among seeds from brown, yellowish-brown, yellow or greenish- yellow fruits, the 1000 -seed weight of seeds from brown fruits was higher than the seeds from other fruit categories. Therefore, we can consider that delayed harvesting (brown fruits) results in high values of seed weight $(678.2 \mathrm{~g})$ and dry weight $(647.6 \mathrm{mg} / \mathrm{seed})$. The highest values of 1000 -seed weight and dry matter content were attained at the same time in tomato (DIAS et al., 2006b) and sweet pepper seeds (VIDIGAL et al., 2011).

The seeds extracted from brown, yellowish-brown, yellow or greenish-yellow fruits had a higher germination percentage and germination at first count than those from green fruits (Table 2). In general, the germination of the seeds from brown, yellowish-brown and yellow fruits did not differ. Kaushik (2003) reported maximum germination of seeds from yellow fruits in relation to brown and green fruits, however seeds from yellowish brown fruits were not tested. The first count can be used as an indicator of seed vigor, because it reflects germination rate. Higher germination rates, indicating high vigour, were obtained for seeds from brown and yellowish-brown especially in relation to those from greenish-yellow and green fruits (Table 2).

Table 2 - Germination (GER), first count of germination (FCG), accelerated aging (AA) e electrical conductivity (EC) of physic nut seeds extracted from fruits harvested at different stages of maturation.

\begin{tabular}{clllc}
\hline Stages & GER & FCG & AA & EC \\
\hline & $\%$ & $\%$ & $\%$ & $\mu \mathrm{cm}^{-1} \mathrm{~g}^{-1}$ \\
Brown & $85 \mathrm{ab}^{*}$ & $84 \mathrm{a}$ & $82 \mathrm{ab}$ & $102.02 \mathrm{ab}$ \\
Yellowish-brown & $88 \mathrm{a}$ & $87 \mathrm{a}$ & $91 \mathrm{a}$ & $82.17 \mathrm{c}$ \\
Yellow & $83 \mathrm{ab}$ & $78 \mathrm{ab}$ & $80 \mathrm{ab}$ & $76.30 \mathrm{c}$ \\
Greenish-yellow & $79 \mathrm{~b}$ & $71 \mathrm{~b}$ & $65 \mathrm{bc}$ & $97.00 \mathrm{~b}$ \\
Green & $74 \mathrm{c}$ & $51 \mathrm{c}$ & $51 \mathrm{c}$ & $113.95 \mathrm{a}$ \\
\hline C.V. $(\%)$ & 9.47 & 9.14 & 13.32 & 5.82 \\
\hline
\end{tabular}

* Means followed by the same letter among fruit stage of maturation are not different (Tukey, $\mathrm{p}<0.05$ ).

The accelerated aging test revealed that there was no significant difference in vigour of seeds obtained from brown, yellowish-brown and yellow fruits (Table 2), which was higher than those of seeds from green fruits. These seeds showed low vigour and did not differ from those obtained from greenish-yellow fruits. It is important to emphasize that germination, first count and electrical conductivity results (Table 2), in general, indicated the seeds from green fruits as having the lowest physiological quality. The lowest values of electrical conductivity (Table 2) were found for the seeds from yellow and yellowish-brown fruits, indicating high vigour, probably due to improving membrane organization along the maturation process. On the other hand, seeds from the green fruits, being immature, have high solute leakage because of incomplete organization of the membrane system (VEIGA et al., 2007; VIDIGAL et al., 2011). High electrical conductivity indicates poor reorganization of the membrane system and consequently low seed vigour (HAMPTON; TEKRONY, 1995). The increase of electrical conductivity of the seed leachates from brown fruits suggests initiation of seed deterioration. This 
process generally starts after maximum vigour (HARRINGTON, 1972). Cellular membrane degeneration is the initial event of seed deterioration that begins soon after physiological maturity (DELOUCHE; BASKIN, 1973). According to Welbaum (1999), in the field, the transition from high quality to aged or even dead muskmelon seeds occurs swiftly over a matter of a few days.

The seedling emergence percentage and the emergence speed index (Table 3) obtained from seeds extracted from green fruits were lower than those obtained from yellowish-brown, yellow or greenish-yellow fruits. However, the values found for seeds from brown fruits did not differ to those obtained from green fruits. There was similar tendency for seedling and radicle length (Table 3 ).

The high seedling growth rate from more vigorous seeds is due to the greater capacity of storage tissues to transform and supply nutrients to the embryonic axis. Table 3 shows that radicle dry weight was higher for seeds from yellowish-brown, yellow or greenish-yellow, which did not differ. Lower values were obtained for green and brown fruits, which did not differ to greenish-yellow results. Thus, seeds from green, brown and greenish-yellow fruits had lower vigour in comparison than those obtained from yellow and yellowish-brown fruits as also observed by the electrical conductivity test (Table 2).

The combination of all results (Tables 1 to 3 ) shows that during seed development and maturation, there are changes in its physical and physiological characteristics, such as size, weight, dry matter content, germination capacity and vigour as described by Bewley and Black (1994). All those changes were accomplished by fruits color alterations (Figure 1); therefore the occurrence of maximum seed quality during development and its association with seed and/or fruit features are important factors to define the ideal harvest time (VIDIGALet al., 2011). We observed that high vigour seeds were obtained from yellow and yellowish-brown fruits, and as the fruits turn brown, the seed deterioration begins resulting in the decline of seed vigour to the level of seeds from green fruits as verified by electrical conductivity, seedling emergence and seedling growth tests (Tables 2 and 3). Although, the dry matter content of the seeds (Table 1) from brown, yellowish-brown, yellow and greenish-yellow fruits did not differ, in general, high quality seeds were obtained when fruits were harvested at yellowishbrown and yellow stages as indicated by most seed quality tests (Tables 2 and 3). On the other hand, seeds from yellowish-brown fruits were always superior to those from greenish-yellow, while these seeds had similar quality level of the seeds from yellow fruits as evaluated by germination, first count and accelerated aging tests.

The seeds from green fruits had less oil compared to the seeds from other fruit categories, which had similar levels of oil (Table 3). This result indicated that accumulation of oil in the seeds coincided with the alterations in dry matter (Table 1). Immature seeds (green fruits) which had lower dry matter content also had low oil content.

In summary, this study shows that the seeds obtained from green fruits are lighter and have less dry weight compared to seeds from brown or yellowish-brown fruits (Table 1). The seeds from green fruits also have lower germination, vigor, and oil content compared to seeds from more mature fruits (Table 2). Therefore, harvesting fruits earlier than the yellow stage results in poor seed quality owing to immaturity.

In general, high physiological quality seeds (Tables 2 and 3) are obtained from yellow and yellowish-brown fruits. Similar results were found by Kaushik (2003), where seeds from yellow capsules showed superior quality over brown black and green capsules. However, this author reported that harvesting fruits after the yellow stage (brown black) did not show any further improvement in seed quality.

Table 3 - Emergence (EM), emergence speed index (ESI), seedling (SL) and radicle (RL) length, radicle dry weight (RDW) and oil content (OC) of physic nut seeds extracted from fruits harvested at different stages of maturation.

\begin{tabular}{ccccccc}
\hline Stages & EM & ESI & SL & RL & RDW & OC \\
\hline Brown & $\%$ & & cm seedling $^{-1}$ & cm seedling $^{-1}$ & mg seedling $^{-1}$ & $\%$ \\
Yellowish-brown & $66 \mathrm{ab}^{*}$ & $2.06 \mathrm{bc}$ & $9.92 \mathrm{ab}$ & $4.35 \mathrm{ab}$ & $16.48 \mathrm{bc}$ & $35.63 \mathrm{a}$ \\
Yellow & $72 \mathrm{a}$ & $2.81 \mathrm{a}$ & $13.61 \mathrm{a}$ & $5.63 \mathrm{a}$ & $28.04 \mathrm{a}$ & $36.43 \mathrm{a}$ \\
Greenish-yellow & $78 \mathrm{a}$ & $3.61 \mathrm{ab}$ & $12.09 \mathrm{a}$ & $5.21 \mathrm{a}$ & $21.48 \mathrm{ab}$ & $35.21 \mathrm{a}$ \\
Green & $48 \mathrm{~b}$ & $1.64 \mathrm{c}$ & $12.51 \mathrm{a}$ & $5.45 \mathrm{a}$ & $19.70 \mathrm{abc}$ & $34.49 \mathrm{a}$ \\
\hline C.V. $(\%)$ & 7.08 & 5.78 & $9.96 \mathrm{~b}$ & $3.05 \mathrm{~b}$ & $10.46 \mathrm{c}$ & $25.94 \mathrm{~b}$ \\
\hline
\end{tabular}

*Means followed by the same letter among fruit stage of maturation are not different (Tukey, $\mathrm{p}<0.05$ ). 


\section{CONCLUSION}

Although seeds from brown fruits had the maximum 1000-seed weight, the highest physiological quality was attained when fruits became yellow and this was retained till the fruits turned yellowish-brown. In situations of inadequate seed supply for marketing, physic nut seeds from brown fruits can still be used, as they maintain high germination potential.

\section{ACKNOWLEDGEMENTS}

The authors acknowledge the Conselho Nacional de Desenvolvimento Científico e Tecnológico (CNPq) and the Fundação de Amparo à Pesquisa de Minas Gerais (FAPEMIG) for providing financial support and the CNPq for fellowship to the first author.

\section{REFERENCES}

ALBUQUERQUE, F.A. et al. Aspectos fisiológicos de sementes de pinhão manso oriundas de frutos colhidos em diferentes estádios de maturação. (Circular Técnica, 124). Campo Grande: Embrapa Algodão, 2008. 5 p.

\section{ASSOCIATION OF OFFICIAL SEED ANALYSTS. Seed} vigor testing handbook. East Lansing: AOSA. 1983. 88p.

BEWLEY, J.D.; BLACK, M. Seeds: physiology of development and germination. 2.ed. New York: Plenum Press, 1994. 445p.

BRASIL. Ministério da Agricultura, Pecuária e Abastecimento. Regras para análise de sementes. Brasília: MAPA/ACS, 2009. 399p.

DELOUCHE, J.C.; BASKIN, C.C. Accelerated aging techniques for predicting the relative storability of seeds lots. Seed Science and Technology, Zürich, v.1, p.427452, 1973.

DIAS, D.C.F.S. et al. Tomato seed quality harvested from different trusses. Seed Science and Technology, Zürich, v.34, p.681-689, 2006a.

DIAS, D.C.F.S. et al. Tomato seed quality in relation to fruit maturation and post-harvest storage. Seed Science and Technology, Zürich, v.34, p.691-699, 2006b.

EGLI, D.B.; TEKRONY, D.M. Species differences in seed water status during seed maturation and germination. Seed Science Research, Wallingford, v.7, p.3-11, 1997.

HAMPTON, J.G.; TEKRONY, D.M. Condutivity test. In: Handbook of vigour test methods. 3.ed. Zürich: ISTA, 1995. p.22-34.

HARRINGTON, J.F. Seed storage longevity. In: KOSLOWSKY, T.T. Seed Biology. 3.ed. New York: Academic Press, 1972. p.145-245.

KAUSHIK, N. Effect of capsule maturity on germination and seedling vigour in Jatropha curcas. Seed Science and Technology, Zürich, v.31, p.449-454, 2003.

MAGUIRE, J.D. Speed of germination-and in selection and evaluation for seeding emergence and vigor. Crop Science, Madison, v.2, p.176-177, 1962.

\section{SAS INSTITUTE INC. SAS/STAT User's Guide version 9.1 Cary. NC: SAS Institute, 2002.}

SILIP, J.J. et al. Lifecycle duration and maturity heterogeneity of Jatropha curcas Linn. Journal of Sustainable Development, Toronto, v.3, p.291-295, Jun. 2010.

TIWARI, A.K.; KUMAR, A.; RAHEMAN, H. Biodiesel production from jatropha oil (Jatropha curcas) with high free fatty acids: an optimized process. Biomass and Bioenergy, Oxford, v.31, p.569-575, 2007.

VEIGA, A.D. et al. Tolerância de sementes de soja à dessecação. Ciência e Agrotecnologia, Lavras, v.31, n.3, p.773-780, maio/jun. 2007.

VIDIGAL, D.S. et al. Changes in seed quality during fruit maturation of sweet pepper. Scientia Agricola, Piracicaba, v.68, p.535-539, Sept/Oct. 2011.

WELBAUM, G.E. Cucurbit seed development and production. HortTechnology, Alexandria, v.9, p.341-348, Jul./Sept. 1999.

ZANAKIS, G.N.; ELLIS, R.H.; SUMMERFIELD, R.J. Seed quality in relation $t$ o seed development and maturation in three genotypes of soybean (Glycine max). Experimental Agriculture, Oxford, v.30, p.139156, 1994. 